\title{
Cytokine profile of rats fed a diet containing shrimp
}

\author{
Perfil das citocinas de ratos alimentados \\ com dieta de camarão
}

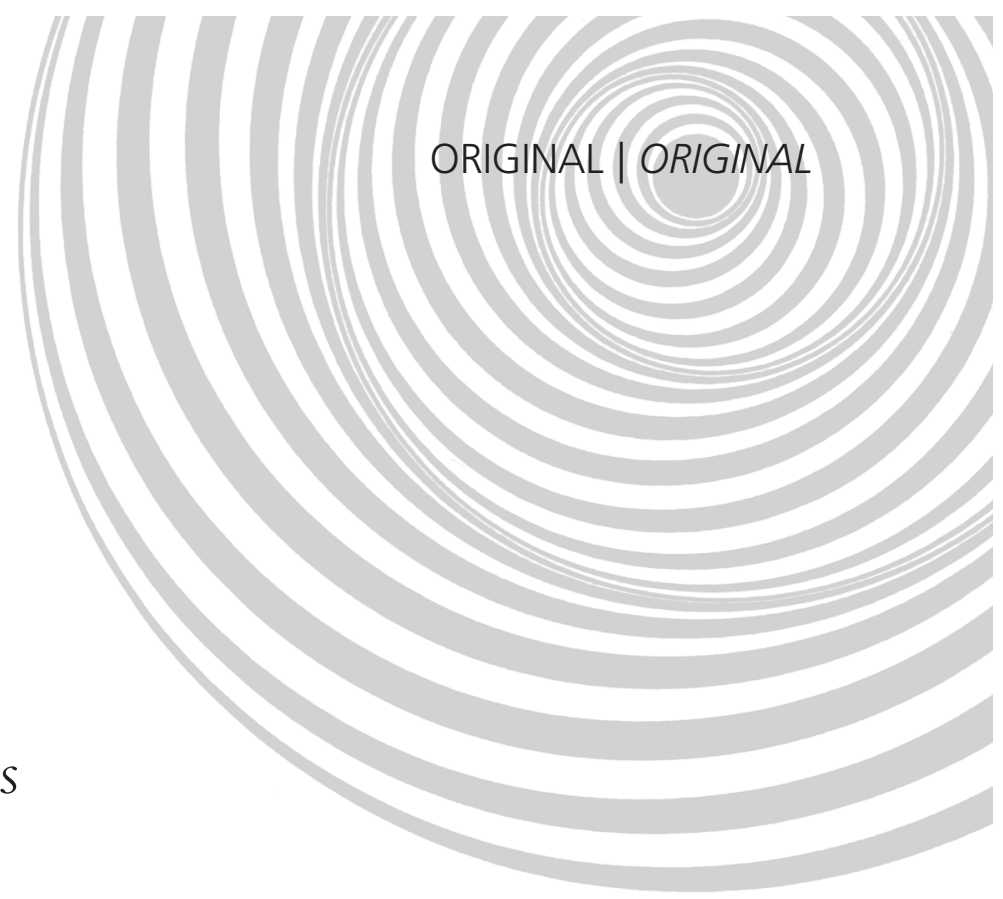

Elizabeth Lage BORGES'

Dirce Ribeiro de OLIVEIRA²

Lucíola da Silva BARCELOS 1

Jorge Luiz PESQUERO'

A B S T R A C T

\section{Objective}

Studies have shown that shrimps reduced the tensile strength of scars in rat skin. The aim of the present study was to assess the cytokine profile of rats fed shrimp.

\section{Methods}

Group 1 (control) received a regular diet and Group 2 (experimental) received a diet containing 33\% shrimp for nine days. The two diets contained the same amounts of proteins, fats and carbohydrates. Serum cytokine levels were determined by ELISA and a segment of the jejunum was taken to investigate its histological morphology and eosinophil infiltrate.

\section{Results}

The experimental group had lower serum levels of interleukin-4 (IL-4) $(14.4 \pm 1.9$ versus $18.11 \pm 2.6 \mathrm{pg} / \mathrm{mL} ; p<0.05)$ and $\mathrm{IL}-10(5.0 \pm 0.98$ versus $7.5 \pm 1.2 \mathrm{pg} / \mathrm{mL} ; p<0.05)$ and higher levels of $\mathrm{IL}-6(17.8 \pm 2.3$ versus $3.2 \pm 0.4 \mathrm{pg} / \mathrm{mL}$, $p<0.001)$ than controls. Morphologically, the shrimp-based diet caused an architectural disorganization of the intestinal mucosa and a greater amount of eosinophils in the jejunal villus.

\section{Conclusion}

Our data suggests that shrimp consumption leads to a significant increase in the cytokine IL-6, a decrease in the immunomodulatory cytokine IL-10 in the serum of rats, and high eosinophil infiltration in the jejunum. The cytokine profile typical of inflammation and the histological aspect of the jejunum are compatible with food allergy.

Indexing terms: Cytokines. Diet. Eosinophils. Interleukins.

\footnotetext{
${ }^{1}$ Universidade Federal de Minas Gerais, Instituto de Ciências Biológicas, Departamento de Fisiologia e Biofísica. Av. Antônio Carlos, 6627, Pampulha, 31270-010, Belo Horizonte, MG, Brasil. Correspondence to/Correspondência para: EL BORGES. E-mail: <borgesel@icb.ufmg.br>.

${ }^{2}$ Universidade Federal de Minas Gerais, Escola de Enfermagem, Departamento de Enfermagem Básica. Belo Horizonte, MG, Brasil.
} 
$60 \mid$ EL BORGES et al.

\section{RE S U M O}

\section{Objetivo}

Estudos mostraram que a dieta suplementada com camarão reduziu a resistência cicatricial na pele de ratos. Nesse contexto, o objetivo do presente estudo foi avaliar o perfil das citocinas de ratos que receberam dieta adicionada com camarão.

\section{Métodos}

Foram comparados um grupo controle e um grupo experimental, que receberam uma dieta enriquecida com camarão (33\%) durante nove dias. As duas dietas continham quantidades semelhantes de proteínas, lipídeos, e carboidratos. Os níveis séricos de citocinas foram avaliados por ELISA, assim como um segmento de jejuno foi obtido para exame histológico da morfologia e infiltrado de eosinófilos.

\section{Resultados}

A dieta adicionada com camarão diminuiu os níveis séricos de $I L-4(14,4 \pm 1,9$ versus $18,11 \pm 2,6 \mathrm{pg} / \mathrm{mL}, p<0,05)$ e $I L-10(5,0 \pm 0,98$ versus $7,5 \pm 1,2 p g / m L, p<0,05$ e aumentou os níveis séricos de $I L-6(3,2 \pm 0,4$ versus $17,8 \pm 2,3 \mathrm{pg} / \mathrm{mL}, p<0,001)$ quando comparada com os animais controle. Morfologicamente, a dieta adicionada com camarão causou uma desorganização da arquitetura da mucosa intestinal, juntamente com uma abundância de eosinófilos nas vilosidades jejunais.

\section{Conclusão}

Os dados sugerem que a ingestão de dieta adicionada com camarão leva a um aumento significativo da citocina IL-6, juntamente com uma diminuição da citocina imunomoduladora IL-10 no soro de ratos e um infiltrado de eosinófilos no jejuno. O padrão inflamatório das citocinas e o aspecto histológico do jejuno são compativeis com alergia alimentar.

Termos de indexação: Citocinas. Dieta. Eosinófilos. Interleucinas.

\section{N T R O D U C T I O N}

Allergen-specific T cells can be isolated from the blood, skin and mucosal sites of patients with food allergy and they characteristically express the allergen-reactive type-2 Thelper (Th2) cell phenotype, releasing interleukins (IL) IL-4, IL-5, and IL-13'. These cytokines play a central role in the induction and maintenance of allergic responses by regulating IgE synthesis, and in the chemoattraction of inflammatory cells, such as mast cells and eosinophils ${ }^{2-5}$. IL-10 can be crossregulated by Th1-related cytokines, such as IL-1 $\beta$, IL-6, inflammatory cytokines. Concurrently, the inflammatory cytokine IL- 6 is capable of promoting Th2 differentiation dependent upon endogenous $\mathrm{IL}-4^{6}$. On the other hand, IL-10, initially considered a Th2-related cytokine, is a regulatory cytokine known to inhibit allergic and inflammatory events ${ }^{7-9}$.

Clinical manifestations of allergic reactions to food may also be seen in the gut because of morphological changes in the intestinal mucosa. Migration leads to significant $T$ lymphocyte accumulation in villus microvessels and in the Peyer's patches via mucosa, in a cell adhesion molecule 1-dependent process. The increased migration of lymphocytes to the intestines might play a key role in the development of intestinal mucosal injury in food allergies ${ }^{10,11}$.

The influence of a shrimp-based diet on the skin wound healing resistance in rats has already been studied ${ }^{12}$. The tensile strength of the scar on the fifth postoperative day was lower in the animals fed shrimp than in the controls. However, the mechanism by which shrimp ingestion affects tensile strength is not clear. The present study considered the hypothesis that this effect may be associated with an allergic process. Therefore, the aim of this study was to determine if the cytokine pattern of rats fed shrimp suggests an allergic process.

\section{METHODS}

Housed Wistar rats weighing 177-302g had access to food and water ad libitum. The 
animals were maintained under standard laboratory conditions of a 12/12-hour light-dark cycle and temperature of $23 \pm 2^{\circ} \mathrm{C}$. The present investigation was in agreement with the Ethical Principles for Animal Experimentation, used by the local Ethics Committee for Animal Experimentation. The composition of the experimental and control diets was described by Borges et al. ${ }^{12}$ and is shown in Table 1. The protein concentration in the dry shrimp flour (made using the shell and flesh of the shrimp) was $33.5 \mathrm{mg} / 100 \mathrm{mg}$ according to the Lowry et al..$^{13}$ method. Both diets contained the same amounts of protein, fats and carbohydrates. The shrimp flour was made by drying commercial shrimp and grinding it until a fine flour was obtained, which was then added to the other components of the diet. The diets were prepared sanitarily, stored at $-20^{\circ} \mathrm{C}$ and removed from the freezer right before use.

Table 1. Diet composition (\%), nutrient contents (g/100g) and energy density (kcal/g).

\begin{tabular}{|c|c|c|}
\hline Ingredients & Control diet & Shrimp-based diet \\
\hline \multicolumn{3}{|l|}{ Diet composition } \\
\hline Corn starch & 57 & 46.9 \\
\hline Casein & 20 & 9.1 \\
\hline Cellulose & 10 & 1.0 \\
\hline Soybean oil & 5 & 3.0 \\
\hline Vitamin mix ${ }^{a}$ & 1 & 1.0 \\
\hline Mineral mix & 5 & 5.0 \\
\hline Choline & 1 & 1.0 \\
\hline Dry shrimp flour & 0 & 33.0 \\
\hline \multicolumn{3}{|c|}{ Macronutrient contents } \\
\hline Proteins & 16.00 & 18.33 \\
\hline Fats & 5.00 & 5.33 \\
\hline Carbohydrates & 52.00 & 42.80 \\
\hline Energy density & 3.25 & 3.00 \\
\hline \multicolumn{3}{|c|}{$\begin{array}{l}\text { aComposition: } 30 \mathrm{mg} \text { niacin, } 15 \mathrm{mg} \text { pantothenic acid, } 6 \mathrm{mg} \text { vitamin } \\
\text { B6, thiamin, } 6 \mathrm{mg} \text { riboflavin, } 2 \mathrm{mg} \text { folic acid, } 750 \mu \mathrm{g} \text { vitamin } \mathrm{K}, 200 \mu \mathrm{g} \\
\text { D-biotin, } 25 \mu \mathrm{g} \text { vitamin B12, } 4000 \mu \mathrm{g} \text {; vitamin A, } 1000 \mu \mathrm{g} \text { vitamin D3 } \\
\text { and } 75 \mu \mathrm{g} \text { vitamin } \mathrm{E} \text {. }\end{array}$} \\
\hline \multicolumn{3}{|c|}{$\begin{array}{l}{ }^{\text {b } C o m p o s i t i o n ~ o f ~ t h e ~ e s s e n t i a l ~ m i n e r a l s: ~} 35 \mathrm{mg} \text { iron, } 5000 \mathrm{mg} \text { calcium, } \\
1561 \mathrm{mg} \text { phosphate, } 3600 \mathrm{mg} \text { potassium, } 300 \mathrm{mg} \text { sulfur, } 1019 \mathrm{mg} \\
\text { sodium, } 1571 \mathrm{mg} \text { chlorine, } 507 \mathrm{mg} \text { magnesium, } 30 \mathrm{mg} \text { zinc, } 10 \mathrm{mg} \\
\text { manganese, } 5 \mathrm{mg} \text { copper, } 0.2 \mathrm{mg} \text { iodine, } 0.15 \mathrm{mg} \text { molybdenum, } 0.15 \mathrm{mg} \\
\text { selenium and potentially beneficial minerals: } 5 \mathrm{mg} \text { silicone, } 1 \mathrm{mg} \\
\text { chromium, } 1 \mathrm{mg} \text { fluorine, } 0.5 \mathrm{mg} \text { nickel, } 0.1 \mathrm{mg} \text { lithium and } 0.1 \mathrm{mg} \\
\text { vanadium. }\end{array}$} \\
\hline
\end{tabular}

Fourteen male Wistar rats were randomly divided into two groups: Group 1 (control) received a regular diet and Group 2 (experimental) received a diet containing 33\% shrimp flour for nine days. Intake of food and water was assessed during the entire experimental period. On the ninth day after initiation of the shrimp-based diet, all rats were anesthetized with thionembutal $(40 \mathrm{mg} / \mathrm{kg}$ intraperitoneally) and submitted to intracardiac puncture. Serum samples were collected and kept frozen at $-80^{\circ} \mathrm{C}$ until analysis. Then, the animals were submitted to laparotomy and segments of the jejunum, below the duodenojejunal ligament were removed. Tissue fragments were rinsed with $0.9 \%$ saline and collected for histological studies after fixation in $10.0 \%$ PBS-buffered formalin.

\section{Cytokines}

Serum samples were quantitatively assayed for IL-1 $\beta$, IL-4, IL-6, and IL-10 by capture Enzyme-Linked Immunosorbent Assay (ELISA) using eBioscience (Iceland, Ireland, United Kingdom) kits. Wells coated with capture antibodies (100 $\mathrm{L}$ per well at appropriate dilution) were incubated with premixed standards or sample supernatants (50 $\mathrm{LL}$ ) in 96-well filter plates. Plates were shaken for $30 \mathrm{sec}$ at 1000rpm and then incubated at room temperature for one hour at 300rpm. After incubation, detection antibodies $(1 \mu \mathrm{g} / \mathrm{mL})$ were added and the plates were shaken and incubated as before. After rinsing with a vacuum device (Millipore Corp., Billerica, MA), avidin-HRP $(2 \mu \mathrm{g} / \mathrm{mL})$ was added to the wells, and the plates were shaken for 30 minutes at room temperature. A substrate solution was added $(100 \mu \mathrm{L}$ per well at appropriate dilution) and incubated at room temperature for another 15 minutes. After addition of a stop solution, the optical density was determined at 450nm.

\section{Histological analysis of the jejunum}

A segment of the jejunum was stored in $10 \%$ buffered formalin and embedded in paraffin. 
Sections of $4 \mu \mathrm{m}$ were prepared and stained with hematoxylin-eosin.

\section{Statistical analysis}

Results are presented as mean \pm Standard Error of Measurement (SEM). The groups were compared by the Student's $t$ test for unpaired data and the level of significance was set at $p \leq 0.05$.

\section{RE S U L T S}

The shrimp-based diet did not change food intake $(37.04 \pm 4.09$ versus $47.22 \pm 24.86 \mathrm{~g})$ for the control and experimental groups, respectively, ( $p>0.05)$ or animal weight $(254.0 \pm 38.2$ versus $264.0 \pm 40.6 \mathrm{~g})$ for the control and experimental groups, respectively $(p>0.05)$. The nutritional status of the animals fed shrimp did not change. There was no weight loss, stunting, thinner and more fragile skin, lethargy or hair loss.

Figure 1 shows the serum concentrations of IL-4 and IL-10. The levels of IL-4 $(14.4 \pm 1.9 \mathrm{pg} / \mathrm{mL})$ and IL-10 $(5.0 \pm 0.98 \mathrm{pg} / \mathrm{mL})$ in the serum of the experimental rats were significantly lower than those of the controls $(18.11 \pm 2.6 \mathrm{pg} / \mathrm{mL}$ and $7.5 \pm 1.2 \mathrm{pg} / \mathrm{mL}$ for IL-4 and IL-10, respectively; $p<0.05)$.

Figure 2 shows the serum levels of the inflammatory cytokine IL-6. The levels of IL-6 in samples from the experimental group $(17.8 \pm 2.3 \mathrm{pg} / \mathrm{mL})$ are significantly higher than those of the control group $(3.2 \pm 0.4 \mathrm{pg} / \mathrm{mL}$, $p<0.001$ ).

The shrimp-based diet did not change the serum levels of IL- $1 \beta(53.1 \pm 4.8$ and $50.4 \pm 5.2 \mathrm{pg} /$ $\mathrm{mL}$ for the control and shrimp-based diet, respectively).

Figure 3 illustrates the histological assessment of the control group's jejuna (Figures $3 \mathrm{~A}$ and $3 \mathrm{~B}$ ) and experimental group's jejuna (Figures 3C and 3D). The shrimp-based diet caused an architectural disorganization of the intestinal mucosa, with inflammatory infiltrate, stressed hyperplasia of calyciform cells (short arrows in C and D) and greater abundance of eosinophil cells in the jejunal villi (long arrows in D) in comparison with the control rats.

\section{DISCUSSION}

The main findings of the present study are the increase in the inflammatory cytokine IL-6 and

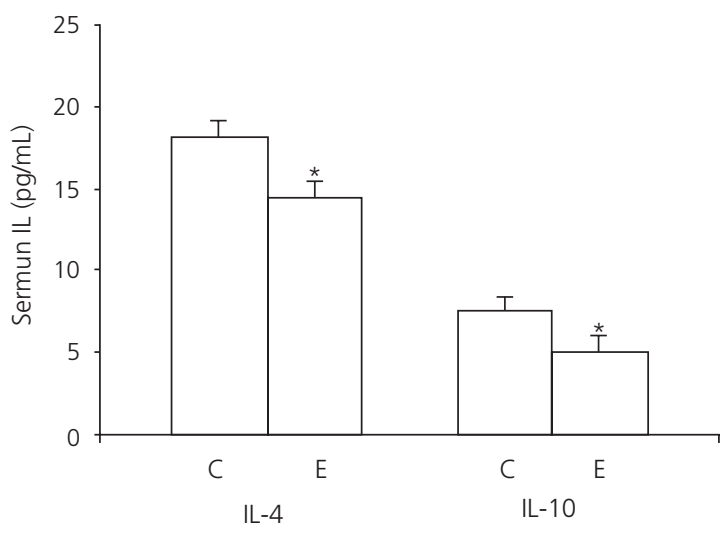

Figure 1. Serum concentrations of IL-4 and IL-10 in rats fed a regular diet (C) or a shrimp-based diet (E).

Note: The data are expressed as means \pm Standard Error of Measurement (SEM) of 7 animals per group. ${ }^{*} p<0.05$ vs. control group.

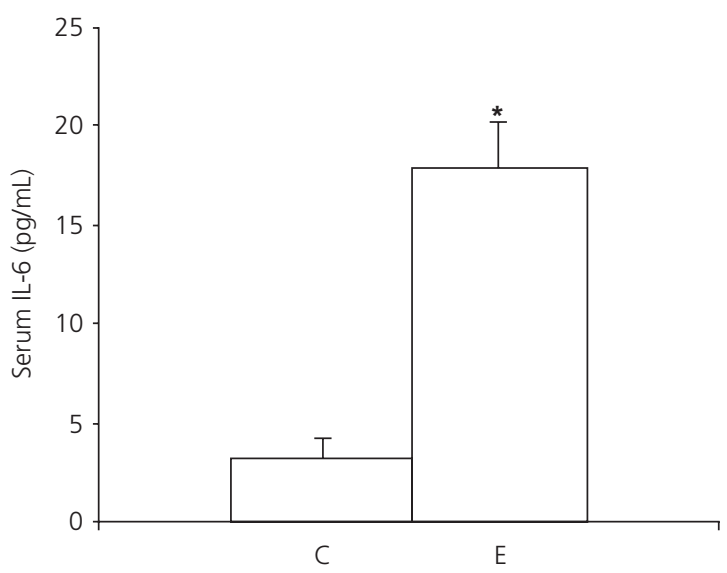

Figure 2. Serum concentrations of IL-6 in rats fed a regular diet (C) or a shrimp-based diet (E).

Note: The data are expressed as means \pm Standard Error or Measurement (SEM) of 7 animals per group. ${ }^{*} p<0.001$ vs. control group. 

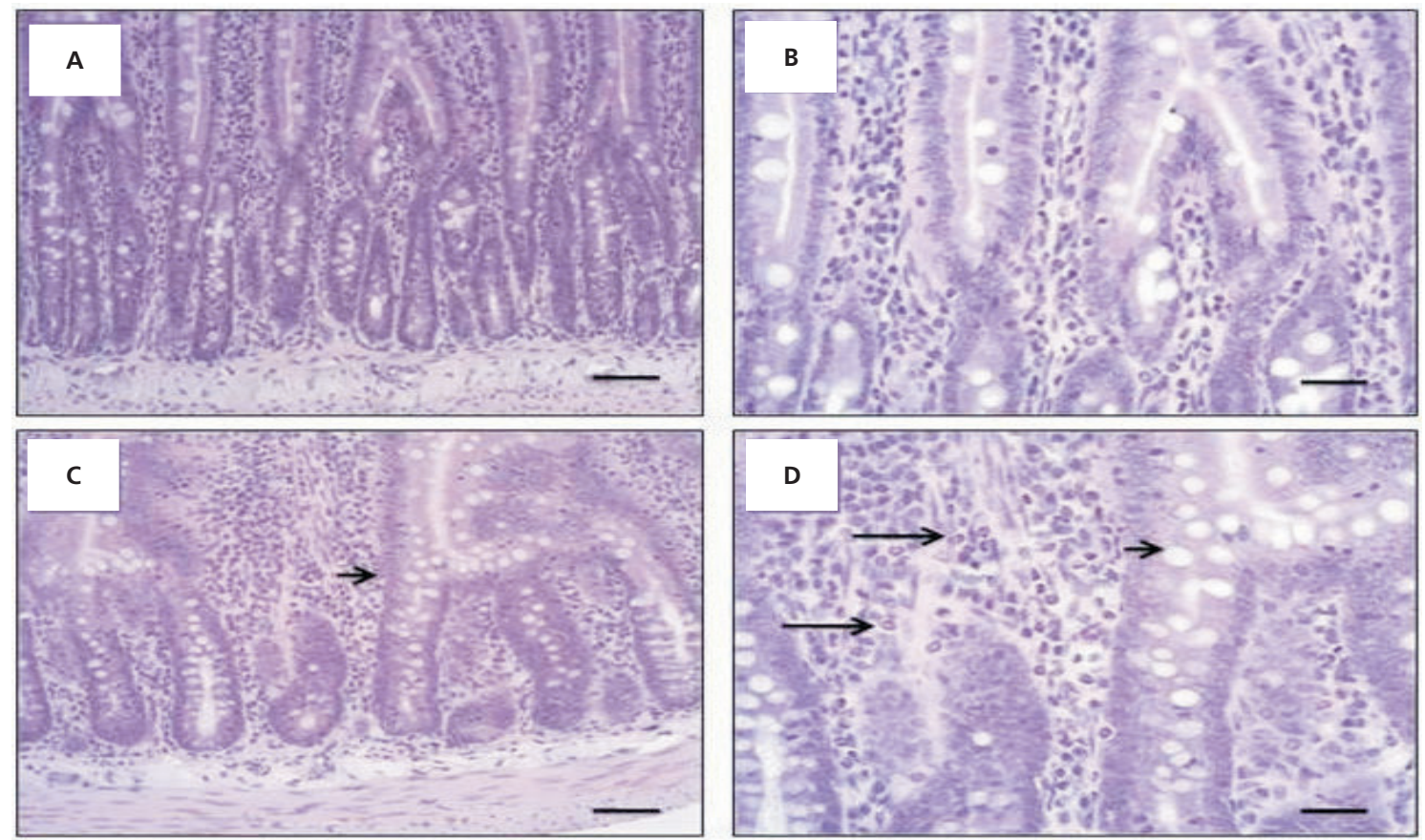

Figure 3. Photomicrographic assessment of rat jejunal mucosa. Histological sections stained with hematoxylin-eosin after control (A and B) and shrimp-based diet (C and D). Inflammatory infiltrate showing hyperplasia of calyciform cells (short arrows in C and D) and greater abundance of eosinophil cells (long arrows in D) in comparison with controls. Original magnification x10 (A and C); ×20 (B and D). Bar=25 $\mu \mathrm{m}$.

the decrease in IL-10, an important regulatory cytokine, in the serum of rats after daily consumption of a shrimp-based diet. No difference in food intake or body weight was observed between the groups and the diet caused a jejunal histological aspect compatible with food allergy.

The high levels of the proinflammatory cytokine IL-6 in the serum of animals in the experimental group could be explained by a number of possibilities, such as an immunespecific effect of some shrimp component or infection by intestinal microbiota. Among these possibilities, the most plausible would be an allergic sensitization caused by the diet. Regulatory T-cells (Treg) might represent a normal braking mechanism leading to tolerance. An emerging hypothesis is that allergic sensitization may result partially from a lack of appropriate IL-10-producing Treg activity, which is either defective or is overcome in those who develop an allergy ${ }^{14}$. Accordingly, an interesting role for IL- 6 in determining Th2 effector and Treg cell function was described by Doganci et al. ${ }^{15}$, who identified IL-6 as an important factor that may expand Th2 responses to allergen and prevent the proliferation of Treg cells in the allergic airway. On the other hand, the allergy in rats fed shrimp-based diet could be facilitated by intestinal bacterial penetration due to intestinal rupture that may accompany a food allergy process as evidenced by the jejunal histology of those animals.

Contrary to IL-6, IL-10 is a regulatory cytokine known to inhibit allergic and inflammatory events $^{7-9}$. IL-10 suppresses macrophage activity and reduces their cytokine production ${ }^{16}$. Temporally, IL-10 expression follows the early proinflammatory cytokine response, probably to limit both the magnitude and the duration of the inflammatory response ${ }^{17}$. In addition, IL-10 may protect children from allergic polysensitization ${ }^{18}$. Therefore, the development of new sensitizations as that caused by the shrimp-based diet may be 
encouraged by low production of some cytokines, especially IL-10, and possibly be related to functional defects of the Treg cells ${ }^{18}$.

While a greater abundance of eosinophils in the jejunal villi of rats in the experimental group was seen, suggesting the occurrence of an allergic food process, there were also low levels of the Th2-related cytokine IL-4. The lower levels of IL-4 could be accounting for an impairment of Treg activity. Indeed, it has been shown that IL-4 can induce the proliferation, as well as prevent Treg apoptosis $^{19,20}$.

Proinflammatory cytokines, including IL-1 $\alpha$ and IL-1 $\beta$, IL- 6 , and TNF- $\alpha$, play an important role in wound repair, influencing processes at the wound site, including stimulation of keratinocyte and fibroblast proliferation, synthesis and breakdown of extracellular-matrix proteins, fibroblast chemotaxis, and regulation of the immune response ${ }^{21}$. Polymorphonuclear leukocytes and macrophages have been shown to be the major source of these cytokines ${ }^{22,23}$. Normal repair seems to occur by the coordinated expression of these cytokines, since expression of these genes was strongly reduced in healing-impaired glucocorticoid-treated mice ${ }^{22}$.

It has been shown that wounds of IL-6knock-out animals took up to three times longer to reepithelialize than those of wild-type controls ${ }^{24}$. The delay in that process and the impairment of granulation tissue formation were probably caused by IL-6 deficiency ${ }^{25}$. Conversely, the opposite effect was observed by administration of recombinant murine IL- 6 protein one hour before wounding, eliminating wound healing impairment, and producing a mitogenic effect on keratinocytes and a chemoattractive effect on neutrophils. Thus, it appears that IL-6 is crucial for kick-starting the healing response. Interestingly, excessive levels of IL- 6 have been associated with skin scarring, and this cytokine increased the most with the shrimp-based diet.

Anti-inflammatory cytokines have also been shown to be important regulators of wound repair. In particular, IL-10 is thought to play a major role in the healing response. This cytokine acts in inflammatory response termination. Moreover, it regulates growth and/or differentiation of various immune cells, but also of keratinocytes and endothelial cells ${ }^{26}$. Based on these activities, a role of IL-10 in wound healing appeared later. In the present study, its serum levels in the experimental rats were lower, which would correspond to the earliest phase of wound repair.

In conclusion, rats receiving a shrimpbased diet display a cytokine profile compatible with allergic processes. This could be contributing to the lower tensile strength of scars observed in those animals after the ingestion of a shrimpbased diet.

\section{ACKNOWLEDGMENTS}

The authors thank Dr. Denise Carmona Cara-Machado for the histological analysis.

\section{CONTRIBUTORS}

EL Borges coordinated and designed the study, performed the statistical analysis and data interpretation, and prepared the manuscript. DR Oliveira prepared the diets and took care of the animals. LS Barcelos aided in the discussion and preparation of the manuscript. JL Pesquero performed the biochemical analysis and preparation of the manuscript.

\section{REFERE NCES}

1. Cribbs RK, Harding PA, Luquette MH, Besner GE. Endogenous production of heparin-like EGF-like growth factor during murine partial-thickness burn wound healing. J Burn Care Rehabil. 2002; 23(2): 116-25.

2. Crowe MJ, Doestschman T, Greenhalgh DG. Delayed wound healing in immunudeficient TGF-beta 1 knockout mice. J Invest Dermatol. 2000; 115(1):3-11.

3. Dammeier J, Beer HD, Brauchle M, Werner S. Dexamethasone is a novel potent inducer of connective tissue growth factor expression: implications for glucocorticoid therapy. J Biol Chem. 1998; 273(29):18185-90. doi: 10.1074/jbc.273.2 9.18185 . 
4. Danilenko DM, Ring BD, Lu JZ, Tarpley JE, Chang $D$, Liu N, et al. New differentiation factor upregulates epidermal migration and integrin expression in excisional wounds. J Clin Invest. 1995; 95(2):842-51.

5. Danilenko DM, Ring BD, Tarpley JE, Morris B, Van GY, Morawiecki A, et al. Growth factoring porcine full and partial thickness burn repair. Differing targets and effects of keratinocyte growth factor, platelet derived growth factor-BB, epidermal growth factor, and neu differentiation factor. Am J Pathol. 1995; 147(5):1261-77.

6. Diehl S, Rincón M. The two faces of IL-6 on Th1/Th2 differentiation. Mol Immunol. 2002; 39(9):531-6.

7. Bundoc VG, Keane-Myers A. IL-10 confers protection from mast cell degranulation in a mouse model of allergic conjunctivitis. Exp Eye Res. 2007; 85(4): 575-9.

8. Koulis A, Robinson DS. The anti-inflammatory effects of interleukin-10 in allergic disease. Clin Exp Allergy. 2000; 30(6):747-50.

9. Tournoy KG, Kips JC, Pauwels RA. Endogenous interleukin-10 suppresses. Allergy. 2000; 30(6): 775-83.

10. Knippels LMJ, Wijk FW, Penninks AH. Food allergy: what do we learn from animal models? Curr Opin Allerg Clin Immunol. 2004; 4(3):205-9.

11. Ogawa T, Miura S, Tsuzuki Y, Ogino T, Teramoto K, Inamura $\mathrm{T}$, et al. Chronic allergy to dietary ovalbumin induces lymphocyte migration to rat small intestinal mucosa that is inhibited by MAdCAM-1. Am J Physiol Gastrointest Liver Physiol. 2004; 286(5):G702-10.

12. Borges EL, Pereira FKS, Alvarez-Leite Jl, Alberti LR, Ferreira MAND, Petroianu A. Shrimp diet and skin healing strength in rats. Rev Nutr. 2007; 20(3):25763. doi: 10.1590/S141552732007000300004.

13. Lowry $\mathrm{OH}$, Rosenbrough NJ, Farr AL, Randal AL. Protein measurement with the Folin phenol reagent. J Biol Chem. 1951; 193(1):265-75.

14. Ahern DJ, Robinson DS. Regulatory $T$ cells as a target for induction of immune tolerance in allergy. Curr Opin Allergy Clin Immunol. 2005; 5(6):531-6.

15. Doganci A, Eigenbrod T, Krug N, De Sanctis GT, Hausding M, Erpenbeck VJ, et al. The IL-6R $\alpha$ chain controls lung CD4+CD25+ Treg development and function during allergic airway inflammation in vivo. J Clin Invest. 2005; 115(2):313-25.

16. Sato $Y$, Ohshima T, Kondo T. Regulatory role of endogenous interleukin-10 in cutaneous inflammatory response of murine wound healing. Biochem Biophys Res Commun. 1999; 265(1):194-9.

17. Zubaidi A, Buie WD, Hart DA, Sigalet D. Temporal expression of cytokines in rat cutaneous, fascial, and intestinal wounds: a comparative study. Dig Dis Sci. 2010; 55(6):1581-8.

18. Prigione I, Morandi F, Tosca MA, Silvestri M, Pistoia V, Ciprandi G, et al. Interferon-gamma and IL-10 may protect from allergic polysensitization in children: preliminary evidence. Allergy. 2010; 65(6):740-2.

19. Chuang YH, Yang YH, Wu SJ, Chiang BL. Gene therapy for allergic diseases. Curr Gen Ther. 2009; 9(3):185-91.

20. Tay SS, Plain KM, Bishop GA. Role of IL-4 and Th2 responses in allograft rejection on tolerance. Curr Opin Organ Transplant. 2009; 14(1):16-22.

21. Werner S, Grose R. Regulation of wound healing by growth factors and cytokines. Physiol Rev. 2003; 83(3):835-70.

22. Hübner $G$, Brauchle $M$, Smola $H$, Madlener $M$, Fassler R, Werner S. Differential regulation of pro-inflammatory cytokines during wound healing in normal and glucocorticoid-treated mice. Cytokine. 1996; 8(7):548-56.

23. Feiken E, Romer J, Eriksen J, Lund LR. Neutrophils express tumor necrosis factor-alpha during mouse skin wound healing. J Invest Dermatol. 1995; 105(1): 120-3.

24. Gallucci RM, Simeonova PP, Matheson JM, Kommineni C, Guriel JL, Sugawara T, et al. Impaired cutaneous wound healing in interleukin-6-deficient and immunosuppressed mice. FASEB J. 14(15): 2525-31.

25. Sato M, Sawamura D, Ina S, Yaguchi T, Hanada K, Hashimoto I. In vivo introduction of the interleukin 6 gene into human keratinocytes: induction of epidermal proliferation by the fully spliced form of interleukin 6, but not by the alternatively spliced form. Arch Dermatol Res. 1999; 291(7-8):400-4. doi: 10.1007/s004030050429.

26. Moore KW, De Waal Malefyt R, Coffman RL, O'Garra A. Interleukin-10 and interleukin-10 receptor. Annu Rev Immunol. 2001; 19:683-765.

Received on: 17/1/2012

Final version on: 18/7/2012

Approved on: 2/10/2012 
